Studia i Materiały, 2/2018 (29), cz. 2: 64-72...

\title{
The Influence of the CRD/CRR Package and the Banking Union on the Banking Market in Poland
}

\begin{abstract}
Matgorzata Mikita*
The CRD/CRR package (Capital Requirements Directive IV / Capital Requirements Regulation) and the banking union have a big influence on all countries within the European Union. The main research problem tackled in the paper is to show the consequences of the $C R D / C R R$ package and the banking union on the banking market in Poland. The paper discusses the main regulations resulting from the CRD/CRR package and the banking union, as well as their influence on the functioning of banks in Poland. Among major regulations there are own funds standards, their liquidity and capital buffers encumbering banking assets. Moreover, three pillars of the banking union, i.e. the Single Supervisory Mechanism, the Single Resolution Mechanism and the Single Deposit Guarantee Scheme, have been also addressed. The main conclusion that can be drawn from the article is the statement that, from the Polish perspective, the CRD/CRR package and the banking union offer more benefits than costs for the financial sector in Poland.
\end{abstract}

Keywords: banking system, EU, Poland, CRD IV, CRR, banking union, European integration.

Submitted: 09.03.18 | Accepted: 17.09.18

\section{Wpływ pakietu CRD/CRR i unii bankowej na rynek bankowy w Polsce}

Pakiet CRD/CRR (Capital Requirements Directive IV/Capital Requirements Regulation) oraz unia bankowa wywieraja istotny wplyw na wszystkie kraje czlonkowskie Unii Europejskiej. Celem artykutu jest analiza konsekwencji wprowadzenia pakietu CRD/CRR oraz ustanowienia unii bankowej dla rynku bankowego w Polsce. W artykule omówiono gtówne regulacje wynikajace z pakietu CRD/CRR i unii bankowej, a także ich wptyw na funkcjonowanie banków w Polsce. Do głównych regulacji wynikajacych z pakietu CRD/CRR zaliczono: regulacje $w$ zakresie funduszy wtasnych i plynność banków, a także bufory kapitatowe obciażajace aktywa bankowe. Analizując wptyw unii bankowej uwzględniono jej trzy filary, tj. jednolity mechanizm nadzorczy, jednolity mechanizm restrukturyzacji $i$ uporzadkowanej likwidacji oraz system jednolitej gwarancji depozytów. Gtównym wnioskiem płynacym z artykułu, jest stwierdzenie, że z polskiej perspektywy, korzyści wynikające z pakietu CRD/CRR i unii bankowej dla sektora finansowego w Polsce przewyżsają koszty.

\footnotetext{
* Małgorzata Mikita - PhD, Department of Capital Markets, Warsaw School of Economics. https://orcid. org/0000-0002-3831-6698.

Correspondence address: Warsaw School of Economics, ul. Madalińskiego 6/8, building M, room 25, 27, secretariat room 10, 02-513 Warsaw; e-mail: malgorzata.mikita@sgh.waw.pl.
} 
Słowa kluczowe: system bankowy, UE, Polska, CRD IV, CRR, unia bankowa, integracja europejska

Nadesłany: 09.03.18 | Zaakceptowany do druku: 17.09.18

JEL: G 15, G 21

\section{Introduction}

The EU aims at financial integration, i.e. unification of rules of functioning of financial markets (Stavrakeva, 2019). The objective of financial integration is to create a market based on the principle of free movement of capital between Member States and the freedom to provide financial services. The process of integration began in 1999 with the implementation of the document named Financial Services Action Plan (FSAP) outlining the legal bases of the functioning of the single financial market (European Commission, 2005). A number of documents have been published (directives, regulations, recommendations, decisions, communications), setting out guidelines as the basis for this market. The common guidelines dealt with the rules of trading in financial instruments on the European market, standardisation of information included in prospectuses, the rules of functioning of investment funds on the EU market, capital requirements for banks and insurance companies, regulations concerning credit rating agencies, common standards in accountancy as well as the rules of trading in derivatives (Deloitte, 2019).

The development of FSAP was completed in 2005 The next phase of integration consisted in transposition of the EU guidelines into the Member States' legislation. This process started in 2006; however, it was not successfully completed due to changes in the EU financial market in 2007-2009. These changes resulted from the financial crisis, which started on the mortgage market in the United States in 2007 and later spread to other countries, including European countries (Pino \& Sharma, 2018). The crisis highlighted the weakness of the European financial system, which could not resist its negative impact. It turned out that financial problems of individual financial institutions swiftly spread across the entire EU market. Therefore, the EU decided to start new reforms in the financial sector. The main aims of these reforms include better regulation of the financial sector, the introduction of efficient supervision and crisis management mechanisms, as well as enhancing the protection of consumers and investors.

A new legal framework for the functioning of banks in the EU countries was defined in 2013 in the CRD (Capital Requirements Directive IV Package) (Directive 2013/36/EU) and in the CRR (Capital Requirements Regulation) (Regulation (EU) No 575/2013). Moreover, one of the most important initiatives aiming at integration of the EU financial market is the establishment of the banking union.

The main research issue tackled in this paper is to present the consequences of financial integration within the $\mathrm{EU}$ for the Polish banking sector. The subject discussed in the paper is highly important due to its timeliness (the banking union is a new, unprecedented concept in the scope of financial integration), as well as its importance for the functioning of financial markets in individual EU countries (the guidelines established at the EU level have a direct impact on the functioning of financial markets in the EU Member States)

In order to evaluate the consequences of financial integration in the EU for the Polish banking sector, a qualitative method was used, involving a comparison of costs and benefits resulting from financial integration for the banking sector in Poland. The qualitative analysis was additionally supported by a presentation of statistical data that reflect the development and security levels in the banking sector in Poland. The study used the most recent statistical data for the Polish banking sector provided by the National Bank of Poland (Narodowy Bank Polski, NBP) and the Polish Financial Supervision Authority (Komisja Nadzoru Finansowego, KNF).

The undertaken studies provided an answer to the question whether financial 
integration within the EU is a beneficial process for the Polish banking sector. The main added value of this article is its usefulness for an assessment of the EU policy concerning the financial market integration. The analysis of the consequences of financial integration within the EU for the Polish banking sector allows for evaluation of the efficiency of the actions undertaken by the EU from the perspective of an individual State, which may be an indication for an efficiency assessment of the financial reforms implemented by the EU.

\section{Financial Integration in the EU - Main Regulations Resulting From the CRD/CRR Package and the Banking Union}

A very significant element from the perspective of financial integration within the EU are the prudential rules defined in the CRD IV/CRR package. They concern, among others, the amount of banks' own funds, their liquidity, as well as capital buffers encumbering banking assets.

Pursuant to the CRR, banks in the EU are obliged to comply with the EU guidelines on the amount of own funds. The total capital ratio may not be lower than $8 \%$, while the ratios indicating the percentage of particular types of capital are defined as:

- the minimal Tier 1 ratio may not be lower than $4.5 \%$ of the risk-weighted assets $^{1}$,

- the minimal Tier 2 ratio may not fall below $6 \%$ of the risk-weighted assets ${ }^{2}$.

If banks comply with the capital ratios defined at the EU level, the security of their functioning is enhanced.

Moreover, the CRR specifies the liquidity requirements for banks. For the purposes of liquidity assessment "liquidity buffers" were introduced - one of them concerns short-term liquidity, whereas the other one relates to long-term liquidity. Short-term liquidity is measured using the short-term liquidity coverage ratio (LCR) It expresses the proportion between high quality liquid assets (HQLA) ${ }^{3}$ and net cash outflows over a 30-day time period (NCO). The target ratio is to be $100 \%$ at least. The LCR has been in effect since 2015; however, a transitional period for its implementation was set until the end of 2018 - during that period the amount of this ratio could be lower than $100 \%$ (in 2017 its minimal amount was fixed at $80 \%$, while in 2018 it was increased up to the minimum level of $90 \%$ ). The LCR introduction aims at providing banks with sufficient liquidity to allow them to independently (i.e. without the help of the central bank) manage difficulties in case of a 30-day period of liquidity stresses. Long-term liquidity is measured using the net stable funding ratio (NSFR). It is a ratio of the available amount of stable funding to the required amount of stable funding. Its minimal target ratio is to be $100 \%$ (Basel Committee on Banking Supervision, 2014). This ratio came into effect in 2018. The aim of the NSFR is to ensure an appropriate ratio between banks' long-term assets and longterm liabilities. The objective is to enhance the safe functioning of banks through an appropriate maturity alignment of their assets and liabilities.

The CRD IV/CRR package also introduced several capital buffers encumbering banking assets. The buffers are applicable along with the standard capital requirements. The introduced buffers include:

- the countercyclical capital buffer (CCB), - the systemic risk buffer,

- the Global Systematically Important Financial Institution (G-SIFI).

The introduction of the CCB aims at reducing the risk connected with the financial cycle phases and at preventing banks from excessive lending. When determining these buffers, the ratio of credits to GDP is taken into account. As for the amount of this ratio, no requirements have been set at the EU level, leaving this issue to the individual Member States.

The aim of the systemic risk buffer introduction is to reduce the non-cyclical systemic risk (Neanidis, 2018). Its amount may be determined independently by the EU Member States. This buffer may be applied to chosen institutions or even to their exposures. The introduction of this buffer is decided by the Ministers of Finance of the individual states.

The G-SIFI concept aims at reducing the risk produced by an individual institution for the stability of the financial system. Such buffers may be applied only to global or local institutions of systemic importance. In the case of global institutions, the maxi- 
mum level of this buffer amounts to $3.5 \%$ of the total risk exposure amount, whereas in the case of local systemically important institutions, this amount is $2 \%$.

An important event in the context of the EU financial market integration was the establishment of the banking union, which consists of three pillars, i.e. the Single Supervisory Mechanism (SSM), the Single Resolution Mechanism (SRM) and the Single Deposit Guarantee Scheme (SDGS) (Xafa, 2015).

The participants in the SSM are the following: the European Systemic Risk Board (ESRB), the European Banking Authority (EBA), the European Insurance and Occupational Pensions Authority (EIOPA), the European Securities and Markets Authority (ESMA), the Joint Committee of the European Supervisory Authorities and the supervisory authorities of the Member States. From the perspective of the banking market surveillance it is the EBA that plays the most important role, along the European Central Bank (ECB), charged with supervising the largest banks of the banking union member states, i.e. banks whose assets exceed EUR 30 billion (ECB, 2014). At present, there are 120 such banks functioning in the Eurozone. The ECB is entitled to verify whether the banks under its control comply with capital adequacy, liquidity and leverage requirements. It can also conduct remedial programmes in banks. Moreover, the ECB is entitled to impose financial sanctions on those banks that fail to comply with prudential rules. In addition to that, the ECB grants authorisations of opening new branches and pursuing cross-border activities in countries outside the banking union. A significant advantage of charging the ECB with supervising competences is that this eliminates situations in which supervisory authorities used to overlook the practices of the largest banks that were facing serious difficulties. Undoubtedly, such practices used to enhance systemic risk, leading to the threat of losing stability of the whole EU financial system.

As for the SRM, two bodies have been established within this buffer: the Single Resolution Board (SRD), which functions as a decision-making authority, and the Single Resolution Fund (SRF), which ensures financial collateral (PWC, 2014).
The SRD monitors the implementation of the resolution programme by national resolution authorities. The main aim of the SRM is to ensure the efficient reorganisation of financial institutions facing problems, as well as liquidation of insolvable financial institutions. The establishment of the SRM, as well as the creation of the SSM, is to strengthen the financial stability in the EU. The SRM lifts the sole responsibility of the Member States' governments for the security of their banking sectors, transferring it also to the SRD. A relevant advantage of the SRM is that it abolishes financing banks at risk from national funds. The obligation to cover banks' losses principally applies to their shareholders and, subsequently, to bank bond holders and depositaries who hold deposits exceeding EUR 100,000 in a given bank. Moreover, the SRM provides that if banks' losses exceed $8 \%$ of their assets, the SRF funds, which are to come from the banks' contribution, will be used to implement the remedial programme. The contributions have been paid since the beginning of 2016 and it is planned that by the end of 2024 (i.e. until the end of the SRF establishment) they will allow for raising EUR 55 billion (Moloney, 2014). If in the future this amount turns out to be insufficient to reorganise the banks, the SRF will raise capital directly on the financial market.

The third pillar of the banking union, namely the SDGS, has not been fully launched yet (Deutsche Bank, 2019). So far, deposit guarantee schemes are of a local nature, i.e. they are determined and monitored by individual Member States. However, the aim is to harmonise legal provisions concerning the protection of deposits up to EUR 100,000. This harmonisation would be implemented, among others, by introducing a rule according to which guarantee schemes in particular countries will be financed from banks' contributions. The minimum level of funds in various countries must amount to $0.8 \%$ of guaranteed deposits (Directive 2009/14/EC). It is also planned to fix a uniform payment delay at 7 days.

The banking union has been joined by all Eurozone states, whereas the other EU Member States can enter it upon close collaboration. 


\section{Benefits and Costs Resulting From the Financial Integration for the Banking Sector in Poland}

Over the last decades the banking sector in Poland underwent significant changes (European Banking Federation, 2018). Some of them resulted from systemic changes in the Polish economy that have been noted since 1989, i.e. following the launch of the construction process of the banking system adapted to the market economy needs. A two-level banking structure was introduced, making it possible to establish new private banks, and foreign investors were allowed to undertake activities in the Polish banking sector. An important part of changes observed in the banking industry in Poland results from Poland's membership in the EU and the necessity to fulfil the EU banking regulations. The integration process of the financial sector, including banking, has been ongoing for 20 years (since 1999), whereas Poland has been a member of the European Union since 2004. Fifteen years of Polish membership in the EU is a period of intensification of the EU work carried out in relation to financial integration. This process was particularly accelerated after 2008, when the EU financial sector was first affected by negative impact of the global financial crisis, started at the turn of 2008 on the mortgage credit market in the United States. Particular importance for the financial market integration is attached to the Capital Requirements Directive IV (CRD IV) package and the Capital Requirements Regulation (CRR), as well as to the establishment of the banking union.

The question arises as to what benefits and costs resulting from financial integration will be relevant for the Polish banking sector. The short duration of the new regulations makes it difficult to conduct a full analysis of costs and benefits. The CRD/CRR package was only introduced 6 years ago, i.e. in 2013, and some of its regulations are not yet in place to the full extent at the moment. The banking union was established in 2014, when its first pillar, namely the Single Supervisory Mechanism, was introduced (the Single Resolution Board was established in January 2015, but it had not become fully operational earlier than January 2016) (Xafa, 2015). The third pillar of the banking union, i.e. the Single
Deposit Guarantee Scheme, has not been introduced yet.

An analysis of the situation in the Polish banking sector in the last two years (2017 and 2018) allows a preliminary assessment of costs and benefits resulting from financial integration in the EU for the banking sector in Poland.

Firstly, it can be concluded that the fact that the banks active in Poland had to comply with regulations concerning the amount of their own funds pursuant to CRR had no negative impact on their functioning. These ratios are maintained in banks in Poland at a much higher level than it is envisaged in the Union regulations. At the moment, the total capital ratio amounts to $19.2 \%$, the Tier 1 capital ratio is $17.3 \%$, whereas the Tier 2 capital ratio is $16.2 \%$ (KNF, 2018a) (data as at September 2018). Moreover, a comparison of these ratios with 2017 ratios points to their increase. The amount of banks' own funds increased both in 2017 and 2018 (KNF, 2018a; KNF, $2018 \mathrm{~b}$ ). This is due to retained earnings generated by many banks, as well new share issuances.

Secondly, no financial liquidity problems were noted in the case of banks in Poland. They fulfil liquidity requirements introduced in Poland in 2008. These requirements are not significantly different from the LCR and the NSFR, although some discrepancies in the classification of assets and liabilities may be noted, differing from the EU guidelines. At the moment banks in Poland make independent decisions concerning this classification, whereas the LCR and NSFR standards provide a precise classification made in accordance with predefined weights. Therefore, it can be said that the liquidity requirements in Poland are less rigorous than the target EU requirements. For many banks the compliance with the NSFR will require a reorganisation of their balance structures so as to move from short-term financing (primarily based on short-term deposits) to medium- and long-term financing (based on medium- and long-term deposits, as well as medium- and long-term debt securities or own funds). As the data presented by KNF indicates, all commercial banks comply with the LCR standard at $100 \%$ level. As for cooperative banks, this standard is not fulfilled by 7 banks of this kind (KNF, 2018a). 
As regards the capital buffers provided for in the CRD IV/CRR package, one of them was introduced in Poland - the systemic risk buffer at the 3\% level. However, introduction of the buffers falls within the discretion of individual Member States.

New prudential rules have not increased the operating costs of banks in Poland in a significant way, although banks' statistical data show that both in 2017 and 2018 banks noted a certain increase in operating costs.

Similarly, the new prudential rules have not affected banks' lending (Kouretas \& Pawłowska, 2018). Credits for the nonfinancial sector increased, both in 2017 and in 2018. An increase was also observed in the case of credits for small and medium enterprises, as well as in the area of credits for large enterprises and households.

Currently, Poland is not a member of the banking union, which is why there is no question of direct benefits or costs resulting from its establishment. However, it is possible to point out certain benefits due to this fact.

Undoubtedly, one of the main benefits is the establishment of the macro-prudential supervision mechanism in Poland in August 2015, namely a supervisory mechanism for systemic risk monitoring (Act of 5 August 2015). The authority responsible for this supervision is the Financial Stability Committee (Komitet Stabilności Finansowej, KSF). It is a collegial body composed of: the President of NBP, the Minister of Finance, the President of KNF and the President of the Bank Guarantee Fund. In addition to systemic risk monitoring, the task of KSF is to perform crisis management where the Polish financial system may cause risks for financial stability. $\mathrm{KSF}$ focuses mainly on reducing the risk resulting from over-indebtedness of financial institutions, excessive use of leverage, as well as mismatches between their receivables and liabilities. Moreover, KSF aims at ensuring appropriate resistance of the financial infrastructure to various stresses, as well as limiting the level of risk-taking by managers. Another area monitored by KSF is financial market liquidity and the concentration of exposures or their similarity and relevant connections between various financial system entities. The establishment of macro-prudential supervision is undoubtedly a significant advantage from the perspective of ensuring stability of the Polish financial system.

The establishment of the Single Supervisory Mechanism (SSM) within the banking union has no direct impact on the functioning of banks in Poland. Banks in Poland are subject to supervision of KNF (Act of 21 July 2006) (except for branches of credit institutions). The largest banks in Poland include: PKO Bank Polski, Pekao SA, Bank Zachodni WBK. These are the only banks whose assets exceed PLN 30 billion and the only ones that would be subject to the ECB's supervision if Poland joined the banking union. KNF supervises the entire Polish financial market. Even though Poland is not a member of the banking union, $\mathrm{KNF}$ follows EBA's recommendations in its activities. Moreover, if a given bank pursuing its activities in Poland is deemed to present systemic risk, KNF is obliged to inform EBA. Supervision over the activities of credit institutions that pursue their activities in Poland through a branch or cross-border activities is performed by the supervisory authorities of the home state. At the moment, there are 15 representative offices of foreign banks and 28 branches of foreign credit institutions functioning in Poland ${ }^{4}$. These branches were established by credit institutions from Germany, Estonia, Luxembourg, France, Spain, Ireland, Denmark, Belgium, the United Kingdom, Portugal, Sweden, Italy and Austria. Branches of foreign banks in Poland are created through the single European passport. On this basis, a credit institution that was authorised to pursue banking activities in one of the European Economic Area (EEA) Member States may pursue activities in other Member States without any additional authorisations. As the host supervisory authority, KNF is entitled to perform supervision only in relation to compliance with paying liquidity standards and anti-money laundering procedures by branches. However, KNF can undertake certain actions if it detects an infringement of the Polish law committed by a branch of a foreign credit institution. At the moment, the share of foreign investors in the assets of the banking sector in Poland amounts to $45.5 \%$ (KNF, 2018a), which means that the banking sector in Poland is dominated by domestic investors. Most of foreign banks pursue their activities in Poland through branches, which is why they are subject to KNF's supervision. 
The institution responsible for sound functioning of the deposit-guarantee scheme in Poland is the Bank Guarantee Fund. The guarantee limit amounts to EUR 100,000. The guarantee covers deposits both in PLN and in foreign currencies; however, the disbursement of guaranteed sums is performed in PLN, regardless of the currency of an account.

The banking union has set out a new approach to the largest banks, i.e. those of systemic importance. It is a group of banks that cause a significant systemic risk. Difficulties faced by individual institutions can trigger consequences for the entire financial system. Even though Poland does not participate in the banking union, it is certainly a beneficiary of the new approach. From the perspective of Poland, it is particularly important to reduce the risk of contagion effect. The Union regulations enhance the stability of functioning of the financial system in the Eurozone by strengthening control over systemically important institutions and thus reduce the risk of financial crisis in Poland. Unfortunately, the drawback of the new solutions is that, at the moment, they fully cover only 19 states belonging to the economic and monetary union, which certainly does not protect Poland against problems of global financial institutions active outside the Eurozone.

The banking sector in Poland is stable and enjoys good financial results. The net result for the whole banking sector in Poland ${ }^{5}$ at the end of 2018 is estimated at more than PLN 14.7 billion. This value is higher than in 2017, when the net result of that sector amounted to PLN 13.6 billion (KNF, 2018a; KNF, 2018b). Undoubtedly, the good situation of banks in Poland is fostered by the environment, e.g. persisting economic recovery, a stable financial situation of enterprises, labour market improvement and a stable situation on the financial market (European Commission, 2019).

\section{Conclusions}

As for the perspective of Poland, financial integration in the EU presents more advantages than disadvantages.

The prudential rules presented in the CRD/CRR package enhance the stability of banks' functioning, which translates directly into increased operating stability of the whole banking sector in the EU and thus reduces the risk of a financial crisis in Poland due to the contagion effect. The establishment of the banking union triggers similar benefits.

The fact that banks in Poland had to align with the requirements set out in the CRD/CRR package has not significantly increased their operating costs. Similarly, the new regulations have not limited the accessibility of credits for enterprises and households. Banks in Poland fulfil own funds requirements provided for in the CRD/CRR package and they do not have any problems with financial liquidity. All commercial banks comply with the LCT standard at the level of $100 \%$.

Poland does not participate in the banking union at the moment, which is why there are no negative aspects involved due to the establishment of the banking union from the perspective of Poland. However, there are some visible positive effects of its creation. One of certain indirect benefits is the establishment of macro-prudential supervision in Poland, which aims at monitoring systemic risk. Another advantage consists in increasing stability of banks' functioning in the Polish market environment.

The process of reforming the financial system in the EU has not yet been completed. The EU is working on further reforms that would empower the system, guarantee its stability and increase the efficiency of its operation.

Among the proposals for new reforms appeared changes regarding in particular: capital requirements, risk assessment, reporting of banks, large exposures, financial leverage, long-term liquidity and banks referred to as TBTF (too big to fail).

The EU underlines that the minimum capital requirements that banks have to meet (set out under Basel III) will not ensure that their losses are covered in the event of bankruptcy. Therefore, new minimum requirements have been introduced for banks' own funds and eligible liabilities. These requirements are specified in the MREL (minimum requirement for own funds and eligible liabilities), introduced by the BRRD (Bank Recovery and Resolution Directive), as well as in the TLAC (Total Loss-Absorbing Capacity) standard presented by the Financial Stability Board (FSB). 
The European Commission is also planning to introduce new principles of credit and market risk assessment, as well as exposure to financial market entities and a central counterparty (CCP). The new standards will apply from 2023.

In addition, new bank reporting and disclosure requirements are planned. A new standard for financial reporting is called IFRS 9 (International Financial Reporting Standard 9).

The new solutions proposed by the EU undoubtedly require their further observation and additional analysis of their influence on the banking market in Poland.

\section{Endnotes}

1 The Tier 1 capital is the capital used to cover losses under the bank's solvency requirements. It is not encumbered by any liabilities. Examples of the Tier 1 capital: capital obtained through common shares issuance, retained earnings, reserve capital or general banking risk reserve.

2 The Tier 2 capital is the capital used to cover losses if a bank loses its solvency. Examples of this capital: instruments with a maturity period exceeding 5 years, e.g. long-term bonds or subordinated loans.

3 Examples of HQLA assets: cash deposited in the central bank, including minimum reserves, securities issued by national governments or entities with zero-risk weighting, securities guaranteed by these countries and entities, as well as debt securities issued by local government institutions, corporate bonds and bonds of high liquidity and high rating.

4 Examples of branches of foreign credit institutions active in Poland: Aareal Bank AG, Banco Espirito Santo de Investimento, S.A., Banco Mais S.A., Banque PSA Finance SA, BNP PARIBAS SA, BNP Paribas Securities Services SA, CaixaBank SA, Calyon SA,CREDIT SUISSE (LUXEMBOURG) S.A., Danske Bank A/S SA, DEPFA BANK plc, Dresdner Bank AG SA, Commerzbank AG SA, Elavon Financial Services Limited, KBL European Private Bankers S.A., Nykredit Realkredit A/S SA, Skandinaviska Enskilda Banken AB (SA), Societe Generale SA, Svenska Handelsbanken AB SA, Sygma Banque Societe Anonyme (SA).

5 The net result indicated for the whole banking sector, including commercial banks, branches of credit institutions active in Poland and cooperative banks.

\section{References}

Act of 5 August 2015 on macroprudential supervision of the financial system and crisis management. Dz. U. (Journal of Laws) of 1 October 2015, 1513.

Act of 21 July 2006 on financial market supervision. Dz. U. (Journal of Laws), 2017, 196.

Basel Committee on Banking Supervision. (2014). Basel III: The net stable funding ratio (Consultative document). Retrieved on 25 April 2017, from http:// www.bis.org/publ/bcbs271.pdf.

Deloitte. (2019). Banking and capital markets outlook. Reimagining transformation. Retrieved from https://www2.deloitte.com/content/dam/Deloitte/ lu/Documents/financial-services/Banking/lu-2019banking-industry-outlook.pdf.

Deutsche Bank. (2019). How to fix European banking ... and why it matters. Retrieved from https:// www.dbresearch.com/PROD/RPS EN-PROD/ PROD0000000000488973/How_to_fix_European_ banking..._and_why_it_matters.pdf.

Directive 2013/36/EU of the European Parliament and of the Council of 26 June 2013 on access to the activity of credit institutions and the prudential supervision of credit institutions and investment firms, amending Directive 2002/87/EC and repealing Directives 2006/48/EC and 2006/49/EC.

Directive 2009/14/EC of the European Parliament and of the Council of 11 March 2009 amending Directive 94/19/EC on deposit-guarantee schemes as regards the coverage level and the payout delay.

ECB. (2016). Financial integration in Europe 2016, April, Frankfurt am Main, Germany. http://dx.doi. org/10.2866/750198. Retrieved from: https:/www. ecb.europa.eu/pub/pdf/other/financialintegrationineurope201604.en.pdf.

EBF. (2018). Banking in Europe: EBF facts \& figures. Retrieved from https://www.ebf.eu/wp-content/ uploads/2018/09/Banking-in-Europe-2018-EBFFacts-and-Figures.pdf.

EC. (2005). White paper - Financial services policy 2005-2010. Brussels.

EC. (2019). Country report Poland 2019. Brussels. Retrieved from https://ec.europa.eu/info/sites/info/ files/file_import/2019-european-semester-countryreport-poland_en.pdf.

KNF. (2018a). Information on the situation of banks in the period I-IX 2018. Warszawa.

KNF. (2018b). Report on the situation of banks in 2017. Warszawa.

Kouretas, G.P., \& Pawłowska, M. (2018). The impact of market structure of the banking sector on the growth of bank loans in the EU after the global financial crisis. NBP Working Paper, No. 277. 
Moloney, N. (2014). European banking union: Assessing its risks and resilience. Common Market Law Review, 51(6), 1609-1670.

Neanidis, K.C. (2018). Volatile capital flows and economic growth: The role of banking supervision. Journal of Financial Stability, 40, 77-79.

Pino, G., \& Sharma, S.C. (2018). On the contagion effect in the US banking sector. Journal of Money, Credit and Banking, 51(1), 261-280.

PWC. (2014). EU bank recovery and resolution directive: „Triumph or tragedy”?. Retrieved on 3 March 2017, from https:/www.pwc.com/im/en/publica- tions/assets/pwc_eu_bank_recovery_and_resolution_directive_triumph_or_tragedy.pdf.

Regulation (EU) No 575/2013 of the European Parliament and of the Council of 26 June 2013 on prudential requirements for credit institutions and investment firms and amending Regulation (EU) No. $648 / 2012$.

Stavrakeva, V. (2019). Optimal bank regulation and fiscal capacity. The Review of Economic Studies.

Xafa, M. (2015). European banking union, three years on. CIGI Papers, (73). 